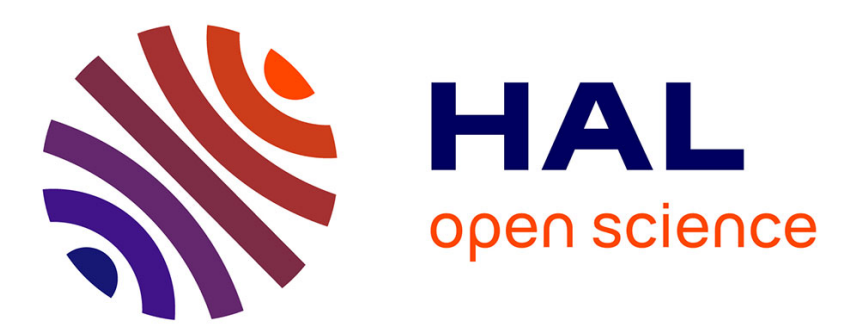

\title{
Improved Isolation of SlaA and SlaB S-layer proteins in Sulfolobus acidocaldarius
}

Pierre Simonin, Carine Lombard, Arnaud Huguet, Adrienne Kish

\section{To cite this version:}

Pierre Simonin, Carine Lombard, Arnaud Huguet, Adrienne Kish. Improved Isolation of SlaA and SlaB S-layer proteins in Sulfolobus acidocaldarius. Extremophiles, 2020, 24, pp.673-680. 10.1007/s00792020-01179-9 . mnhn-02862458

\section{HAL Id: mnhn-02862458}

\section{https://hal-mnhn.archives-ouvertes.fr/mnhn-02862458}

Submitted on 17 Nov 2020

HAL is a multi-disciplinary open access archive for the deposit and dissemination of scientific research documents, whether they are published or not. The documents may come from teaching and research institutions in France or abroad, or from public or private research centers.
L'archive ouverte pluridisciplinaire HAL, est destinée au dépôt et à la diffusion de documents scientifiques de niveau recherche, publiés ou non, émanant des établissements d'enseignement et de recherche français ou étrangers, des laboratoires publics ou privés. 
Title: Improved Isolation of SlaA and SlaB S-layer Proteins in Sulfolobus acidocaldarius

Authors and Affiliations: Pierre Simonin ${ }^{1}$, Carine Lombard ${ }^{1}$, Arnaud Huguet ${ }^{2}$, and Adrienne Kish ${ }^{1 *}$

${ }^{1}$ Muséum national d'Histoire naturelle, CNRS, Unité Molécules de Communication et Adaptation des Microorganismes UMR7245 MCAM, CP54, 57 rue Cuvier, 75005 Paris, France

${ }^{2}$ Sorbonne University, CNRS, EPHE, UMR 7619 METIS, 4, place Jussieu, Paris 75005, France

*Corresponding Author: Adrienne Kish, email: adrienne.kish@mnhn.fr

\section{List of Abbreviations:}

SDS = sodium dodecyl sulfate

SDS-PAGE = sodium dodecyl sulfate polyacrylamide gel electrophoresi

HEPES = 4-(2-hydroxyethyl)-1-piperazineethanesulfonic acid

$\mathrm{EDTA}=$ Ethylenediaminetetraacetic acid

$\mathrm{MeOH}=$ Methanol

$\mathrm{DCM}=$ Dichloromethane

HPLC-APCI-MS = high performance liquid chromatograny-atmospheric pressure chemical ionization mass spectrometry

GDGT $=$ glycerol dialkyl glycerol tetraethers 


\section{Abstract:} the ordered structure of the S-layer matrix, and SlaB, which supports and anchors the S-layer in the tetraether lipid membrane. Large batch-scale methods using starting culture volumes of 20-70 L have been developed for the isolation of the SlaA protein from the rest of the cell envelope. These methods rely on the thermotolerance of SlaA and its high resistance to detergents. SlaB, however, remains strongly associated in a large molecular weight aggregate with other cell envelope components, even after removal of the remaining cellular contents. Here we demonstrate a protocol for benchtop-scale (1-2 L) purification of S-layer proteins. Using this protocol, we were also able to identify for the first time the tetraether lipids strongly attached to SlaB.

Keywords: S-layer, cell wall, Sulfolobus acidocaldarius, Archaea, protein purifigation, SlaA, SlaB

\section{Introduction:}

The cell walls of extremophilic microorganisms provides both vital protection from potentially damaging agents, as well as an interface for interactionswith both other organisms and abiotic elements in the external environment. Cellval composition varies between different taxonomic groups, but most major phylogen tie groups of bacteria and archaea include cell walls containing proteinaceous surfacedsyers (or S-layers) (Zhu et al. 2017). S-layers can in fact be the sole component of the all wall for many extremophilic archaea.

S-layers are a self-assembling matrix of repeatedorotein monomers, often bearing posttranslational modifications such as glycosylations, that can modify the interactions between cell surfaces and their surrounding biotic abiotic environment. The symmetry of the Slayer is determined by the number of minomers composing the repeated structural unit: oblique (P2), square (P4), or hexagorg (P3 or P6). S-layer proteins are one of the most abundant cellular proteins, compegrig in excess of $10 \%$ of total protein (Sleytr et al. 2011). S-layers are known to have seltes in structural support, cell adhesion, and virulence (Engelhardt 2007a). The rive been shown to play key roles in the survival of extremophiles under stress conditionofncluding salinity and osmotic stress (Engelhardt 2007b; Guan et al. 2012; Im et al. 2013), metal stress (Chandramohan et al. 2018), radionuclides (Merroun et al. 2005; Reitz et al@015), thermal stress and mechanical stress (Mader et al. 1999) as well as enhancing USR Sistance (Farci et al. 2017). S-layers have been harnessed for biotechnology application ranging from materials science, to metal biomining and bioremediation, to drug delivery systems (Sleytr et al. 2011; Bartolomé et al. 2012; Sleytr et al. 2014; Ucisik et al.

\section{0}

S-ayer proteins show little sequence conservation between the Bacteria and Archaea. Even within the Archaea there is wide variance in the S-layer protein primary sequences and posttranslational modifications, as well as S-layer matrix symmetries, structures, and interactions with the cell membrane and other cell envelope components (Albers and Meyer 2011; Rodrigues-Oliveira et al. 2017). No complete crystal structure has been resolved to date for archaeal S-layer proteins. The lack of conservation inhibits the development of "universal" Slayer tools, such as universal S-layer recognition antibodies. Studies of S-layer proteins must therefore be tailored to each taxonomic group, often employing model species. 
The hyperthermoacidophilic Sulfolobus acidocaldarius has served as a key model for studying the S-layers of archaea since its isolation in 1972 (Brock et al. 1972). Like other Sulfolobus species, the S-layers of $S$. acidocaldarius are composed of monomers of the SlaA protein self-assembled into a hexagonal array with threefold (P3) symmetry (Lembcke et al. 1991), and anchored into a tetraether monolayer cell membrane by the SlaB protein proteins (Veith et al. 2009; Gambelli et al. 2019). Both SlaA and SlaB are known to be Nglycosylated (Peyfoon et al. 2010; Guan et al. 2016). While Sulfolobus species share the same the basic S-layer structure, the primary sequence of SlaA and SlaB share only $24-25 \%$ identify with other species such as $S$. islandicus and S. solfataricus \{Gambelli:2019hd\}. The S-layer proteins of $S$. acidocaldarius also show far greater stability against detergents than? other Sulfolobus species. While Sulfolobus solfataricus and Sulfolobus brierleyi are only mildly resistant to hot detergent (SDS) treatments, S. acidocaldarius was shown to bo $h$ ighly resistant (König and Stetter 1986). Treatment with room temperature $10 \%$ SDS res llted in Slayer sheets, but the $S$. acidocaldarius S-layer proteins remained insoluble up torratment with $10 \%$ SDS at $90{ }^{\circ} \mathrm{C}$ (Weiss 1974).

Many aspects of the S-layer structure and function can be studied using nole cells, however isolation and purification of the S-layer proteins is needed to separate trie roles of SlaA and SlaB from those of the other cell envelope components. Despite the simplistic structure of the Sulfolobus cell envelope, isolation of the S-layer proteins is caticated by the fact that after an initial cell disruption and removal of the cellular content, S-layer-containing cell-free sacculi retain the same morphology as whole cells. Thes exacculi or "ghosts" can contain the complete cell envelope (cell membrane, SlaA, SlaB); Ponly the cell wall (S-layer only, no cell membrane).

Early extractions of the $S$. acidocaldarius cen envelope lysed cells using either a French press, or detergents $(0.15 \%$ SDS with 10 EDTA) to aid in destabilizing the cell envelope (Weiss 1974; Michel et al. 19\%). Grogan (1989) developed a generalized Sulfolobus S-layer purification proto 81 using $0.4 \% \mathrm{~N}$-lauryl sarcosine in buffer $(\mathrm{pH} 5)$ to lyse cells and DNase treatment tocesuce the lysate viscosity, followed by repeated cycles of treatment with the same solutior heated to $56{ }^{\circ} \mathrm{C}$ and centrifugation to remove cellular debris, eventually producing a whitit upper phase containing the S-layer proteins overlaying the brownish cell pellet. The 1 her resistance of $S$. acidocaldarius S-layer proteins to detergent treatments compared tother Sulfolobus species were exploited to permitted better separation of the S-layer proteins from the underlying cell membrane. Lipid removal was found to be more effective u. cultures for enctions, it was found that following an initial cell lysis, repeated hot $\left(60{ }^{\circ} \mathrm{C}\right)$ SDS treatronts could be employed to separate $S$. acidocaldarius S-layers from other cellular proteins (Michel et al. 1980). SDS was subsequently removed by 6-8 washes in deionized $\mathrm{H}_{2} \mathrm{O} \bigcirc \mathrm{H}_{2} \mathrm{O}$ ). This protocol became the standard for $S$. acidocaldarius S-layer extractions. However, the composition of the protein extracts (SlaA, SlaB) varied between labs. Using the same protocol and the same strain of $S$. acidocaldarius, one group reported obtaining S-layer sacculi composed of both SlaA and SlaB proteins (Michel et al. 1980), while others reported obtaining pure SlaA "ghosts" retaining cell-type morphology (Selenska-Pobel et al. 2011; Reitz et al. 2015). The quantity of cell culture used for extraction also affects the quality of the extracts. Following the same protocol, but using only $1 \mathrm{~L}$ of exponential-phase culture instead of large batch cultures (20-70 L), we obtained S-layer ghosts with both SlaA and B proteins rather than pure SlaA (Kish et al. 2016). 
The inability to properly down-scaling the S-layer extraction protocol to benchtop scale (1-2 L) cultures, as well as the difficulties encountered isolating SlaB, likely due to the strong association of SlaB with so-far unidentified molecules in the cell envelope, inhibit routine studies of S-layer protein structure and function.

Here we present a method for a benchtop-scale purification of SlaA and SlaB proteins, as well as characterization of the molecules strongly associated with the SlaB anchor protein.

\section{Methods and Results:}

111

The purification of SlaA and SlaB proteins followed three main steps: preparation of cell envelope extracts, separation of SlaA and SlaB, and finally removal of membrane lipids SlaB.

Culture growth and preparation of S-layer-enriched cell envelope extracts Sulfolobus acidocaldarius DSM 639 cells were cultivated in Brock's medintpeBrock et al. 1972) $\mathrm{pH} 3.5$ supplemented with $0.1 \%$ yeast extract and $0.2 \% \mathrm{D}$-saccharegelat $80{ }^{\circ} \mathrm{C}$ with agitation $(170 \mathrm{rpm})$ in $1 \mathrm{~L}$ Erlenmeyer flasks with specialty-made exterded glass aeration necks in a shaking oil bath until mid-exponential growth phase $\left(\mathrm{OP}_{609 \mathrm{~nm}}=0.5\right)$. The cells were harvested by centrifugation $(8000 \mathrm{x} \mathrm{g}, 10 \mathrm{~min}$ ), and the cell pellet resulting from roughly $1 \mathrm{~L}$ of culture were flash frozen in liquid nitrogen and stored at $-80^{\circ} \mathrm{C}$ until use for S-layer protein extraction.

To purify the S-layer proteins, we first isolated the S-1.Qer containing cell envelope using a modified version of the protocol of Reitz et al. (Reifeet al. 2015), adapted to benchtop-scale volumes $\left(1-2 \mathrm{~L}\right.$ cell culture at $\left.\mathrm{OD}_{600 \mathrm{~nm}}=0.5\right)$ rathe 8 than bioreactor-scale volumes $(70 \mathrm{~L})$ used in previous studies. The cell pellet was gentl thawed on ice and resuspended in HEPES buffer $(10 \mathrm{mM}, \mathrm{pH} 7)$ at $4{ }^{\circ} \mathrm{C}$ containing $20 \mathrm{M}$ EDTA to inhibit metalloproteases as well as chelate any cations attached to anionic atlet of the tetraether membrane (Pineda De Castro et al. 2016), and $1 \mathrm{mM}$ Pefabloc SC 18inhibit serine proteases (Fusi et al. 1991). Preliminary disruption of cell membranes andogitubilization of proteins was achieved using a denaturing, anionic detergent $(0.15 \%$ SDS $)$ DNA was digested by addition of $100 \mu \mathrm{g} / \mu 1$ DNase I and 4 $\mathrm{mM} \mathrm{MgCl} 2$ for $1 \mathrm{~h}$ at $37^{\circ} \mathrm{C}$-reduce the viscosity of the cell lysate. Further solubilization of the cell lysate and cell mororane was then performed by overnight incubation in $2 \%$ SDS at room temperature witbgentle agitation $(50 \mathrm{rpm})$. Insoluble S-layer components were separated from therest of the solubilized cell lysate by centrifugation (40 $000 \mathrm{x} \mathrm{g}, 45 \mathrm{~min}$ ). The white upper chffuse layer containing the cell envelope was removed from the more compact, darlo beige phase underneath, resuspended in the same buffer, and centrifuged as before. ThoSDS was then removed from the resulting cell layer extracts by eight washes in $\mathrm{dIH}_{2} \mathrm{O}$ (centrifugation at $40000 \mathrm{x} \mathrm{g}, 45 \mathrm{~min}$ between each wash step), and the protein comporents of extracts analyzed by SDS-PAGE.

142 This enriched S-layer protein sample obtained by hot SDS extraction was then analyzed by

143 SDS-PAGE. Solubilization of the proteins prior to electrophoretic migration was accomplished by incubation in $20 \mathrm{mM}$ sodium carbonate buffer $(\mathrm{pH} 10)$ at $65^{\circ} \mathrm{C}$ for $30 \mathrm{~min}$. Laemmli buffer was then added and the proteins denatured at $95^{\circ} \mathrm{C}$ for $5 \mathrm{~min}$ prior to separation by SDS-PAGE (10\% gel), and visualized by Coomassie staining. The only two bands visible (apparent masses near $120 \mathrm{kDa}$ and $55 \mathrm{kDa}$ ) corresponded to the previously established apparent molecular masses for polypeptides determined by mass spectrometry to be SlaA and SlaB, respectively (Kish et al. 2016) (see Figure 1). More SlaA was isolated than $\mathrm{SlaB}$, which is coherent with the model for Sulfolobus S-layer structure, with six SlaA 
proteins composing the hexameric S-layer array anchored by three SlaB proteins (Veith et al. 2009).

After removal of the supernatant, the resulting pellet contains two differently colored phases: a lower, darker beige phase containing cell lysate and a whitish upper phase containing the cell envelope. Previous protocols manually separated the whitish phase from the rest of the pellet (Reitz et al. 2015). However, in practice obtaining a cell pellet sufficiently large to easily manually separate the whitish phase from the darker phase is only possible when starting from batch-scale culture volumes, such as the $70 \mathrm{~L}$ bioreactor used by Reitz et al. (Reitz et al. 2015), which are not readily available. To separate the SlaA and SlaB proteins, we instead used size exclusion chromatography.

\section{Separation of SlaA and SlaB by size exclusion chromatography}

The S-layer suspension in $20 \mathrm{mM}$ Na-carbonate buffer (pH 10) was injected in o Superdex 200 (GE Healthcare) size exclusion chromatography column. Figure 2 shoy two peaks: the first is an exclusion peak (panel A; peak 1), whereas the sogond one corresponds to purified SlaA monomers (panel A; peak 2). The purified Na monomers were collected. In order to ensure that no SlaA monomers were mixed with SlaB proteins in the excluded fraction, this fraction was reinjected and separated $1 \times$ el filtration (Figure 2B; peak $\left.1^{\prime}\right)$. The resulting fractions from both injections were storat $4{ }^{\circ} \mathrm{C}$. Separation of the isolated proteins by SDS-PAGE (10\% gel; see Figure 3$)$ redaled the expected apparent molecular masses for purified $\mathrm{SlaB}$ and SlaA proteins inde first and second fractions, respectively.

While this shows that the SlaA and SlaB proteins rere successfully separated from all other proteins, the chromatogram for the elution of the SlaB protein corresponds to a larger mass than would be expected for SlaB monomen OWe hypothesized that SlaB monomers were aggregating, either due to hydrophobic Areractions between SlaB proteins, or due to the presence of membrane tetraether lipiss still associated with the SlaB protein. To test the hypothesis that lipids were remaicy in association with SlaB even after treatment with $2 \%$ SDS, we subjected the enrichedSlaB fraction to lipid extraction.

Extraction and identificarif of membrane lipids associated with SlaB (Figure 2B, peak 1') was dried using a rotary evaporator. Lipid extraction from the dried sample was perfoned using a modified Bligh and Dyer method based on Huguet et al. (2013). Briefty samples were resuspended in an extraction mix of methanol $(\mathrm{MeOH}): \mathrm{P}$ chroromethane (DCM):Buffer (either phosphate buffer $(50 \mathrm{mM}, \mathrm{pH} 7.4)$ or Na189 carbonate buffer $(40 \mathrm{mM}, \mathrm{pH} 10))(2: 1: 0.8 \mathrm{v} / \mathrm{v} / \mathrm{v})$, and placed in an ultrasonic bath (Branson 19035100 or $10 \mathrm{~min}$. The MeOH:DCM:Buffer (Phosphate or Na-carbonate) volume ratio was 191 tho adjusted to $1: 1: 0.9$, followed by centrifugation $(500 \mathrm{x} \mathrm{g,} 10 \mathrm{~min})$, and collection of the 192 exuracts in a separation funnel. The DCM layer containing the lipids was separated from the 193 MeOH: Buffer (Phosphate or Na-carbonate) layer and then extracted three more times with DCM, with the resulting DCM fractions combined and dried over $\mathrm{Na}_{2} \mathrm{SO}_{4}$. For extraction of lipids from the enriched SlaB suspension, Na-carbonate $(40 \mathrm{mM}, \mathrm{pH} 10)$ was used.

The lipid extract was then re-dissolved in $200 \mu \mathrm{L}$ heptane and centrifuged using an Eppendorf Mini Spin centrifuge (1 min, $7000 \mathrm{rpm}$ ). The supernatant was collected and analyzed using high performance liquid chromatography-atmospheric pressure chemical ionization mass spectrometry (HPLC-APCI-MS). Tetraether analyses were performed as 


\section{Discussion :} limit of $1 \mathrm{ppb}$. mass.

recently described by Huguet et al. (2019). Briefly, tetraether separation was achieved with two silica columns in tandem $(150 \mathrm{~mm} \times 2.1 \mathrm{~mm}, 1.9 \mu \mathrm{m}$, Thermo Finnigan; USA) thermostated at $40{ }^{\circ} \mathrm{C}$. Injection volume was $30 \mu \mathrm{l}$. GDGTs were first eluted isocratically with $82 \% \mathrm{~A} / 18 \% \mathrm{~B}$ for $25 \min (\mathrm{A}=$ hexane, $\mathrm{B}=$ hexane/isopropanol $9 / 1, \mathrm{v} / \mathrm{v})$. The following linear gradient was subsequently used: $82 \% \mathrm{~A} / 18 \% \mathrm{~B}$ to $65 \% \mathrm{~A} / 35 \% \mathrm{~B}$ in 25 min, followed by $65 \% \mathrm{~A} / 35 \% \mathrm{~B}$ to $100 \% \mathrm{~B}$, maintained for $10 \mathrm{~min}$ and then back to $82 \%$ $\mathrm{A} / 18 \% \mathrm{~B}$ in $10 \mathrm{~min}$, maintained for $30 \mathrm{~min}$. The flow rate was set at $0.2 \mathrm{ml} / \mathrm{min}$.

HPLC-APCI-MS analysis enabled detection of two tetraether lipids in the sample of purified SlaB proteins, identified on the chromatogram as two peaks with mass to charge ratios $(\mathrm{m} / \mathrm{z}$ of 1296 at $10.7 \mathrm{~min}$, and 1294 at $11.4 \mathrm{~min}$ (Figure 4A). These masses correspond to th cyclopentane ring-bearing glycerol dialkyl glycerol tetraethers (GDGTs) GDGT-3 a GDGT-4, respectively (Hopmans et al. 2000; Zeng et al. 2019).

To ensure that no other lipids remained attached to the SlaB proteins after lipfoextraction, the SlaB proteins obtained after solvent-based lipid extraction were first applied to a Superdex 200 (GE Healthcare) size exclusion chromatography column. Nhe resulting protein fraction was then subjected to a second round of solvent-based lipid extraction using the same protocol as previously, using phosphate buffer $(50 \mathrm{mM}, \mathrm{pH}$-4) instead of Nacarbonate buffer, after which no lipids were detected (Figure $4^{*}$ ) with a minimum detection

Having identified that GDGTs were in fact associated 0 th SlaB after hot SDS treatment and size exclusion chromatography, we sought to remosethe lipids from the original SlaB protein aggregate obtained after hot SDS treatme (Figure 2B, peak 1') was first solubilized in an equal volume of $20 \mathrm{mM} \mathrm{Na-carbonate} \mathrm{buffer}$ $(\mathrm{pH} \mathrm{10})$ and then treated it with $1 \% \mathrm{CHAR}$ for $30 \mathrm{~min}$ at $37^{\circ} \mathrm{C}$ with agitation. To check whether this treatment was sufficient foc Nemoval of the GDGTs associated with SlaB, the CHAPS-treated solution was first apged to a Superdex 200 size exclusion chromatography column to isolate the SlaB proteire which were excluded from the column, followed by lipid extraction following the same modified Bligh and Dyer method described above using phosphate buffer (50 mM, 10 7.4). HPLC-APCI-MS analyses failed to detected any tetraether lipids in associton with SlaB. The exclusion of SlaB proteins from the Superdex 200 resin indicates thagaespite the removal of residual GDGTs by CHAPS following hot SDS isolation of the S-layer proteins, the SlaB proteins remained associated in an aggregate

Taken tog ther, these results suggest that the larger mass observed during elution for purified SlaB was due to both strong association with GDGTs and likely auto-aggregation of hydrohobic, N-terminal transmembrane domain of the SlaB protein (Veith et al. 2009).

Here we present a method for complete isolation of SlaA from SlaB, starting from benchscale culture volumes. This method improves upon existing protocols by allowing for reduced quantities of cell cultures to be used. In our study, the SlaA was found to have an apparent molecular mass of $120 \mathrm{kDa}$, despite the calculated molecular mass of $151 \mathrm{kDa}$ based on its primary sequence (Claus et al. 2005). Previous studies have observed a range of apparent molecular weights for SlaA from $S$. acidocaldarius DSM 639 up to $170 \mathrm{kDa}$ (Michel et al. 1980; Grogan 1989; Selenska-Pobel et al. 2011). Some early studies have even 
shown two high-molecular weight bands for the SlaA protein $(140 \mathrm{kDa}$ and $170 \mathrm{kDa})$ that were determined by their amino acid composition to be the same SlaA protein (Michel et al. 1980). This difference in the electrophoretic mobility of $S$. acidocaldarius S-layer proteins has been attributed to protein glycosylations, as well as their low solubility in acidic or neutral hot SDS (Grogan 1996). In addition, S-layer proteins remain insoluble in the neutral pH Laemmli buffer containing SDS, and so prior to electrophoretic migration, S-layer proteins must be solubilized in a heated in alkaline buffer (Grogan 1989; Selenska-Pobel et al. 2011; Guan et al. 2016). S-layer proteins from other archaea have shown altered electrophoretic migration depending on culturing conditions including temperature, $\mathrm{pH}$, and protein maturation events (Konrad and Eichler 2002; Claus et al. 2005). While the reasons (1) these differences in electrophoretic mobility are still unknown, attention must therefore paid when comparing results between studies using different strains of the same orgat $\mathrm{m}$, as well as the culturing and protein solubilization conditions.

This protocol allowed us to identify for the first time that the molecules agging with SlaB in strong association are GDGTs. The interaction between SlaB S-lay ar anchor protein and membrane tetraether lipids was shown to be highly resistant, even Dheat and detergent treatments. Less SlaB is present than SlaA, even in whole cells, coherent with the current model for Sulfolobus S-layer structure with twice as much SlaA a SlaB (Veith et al. 2009). There is likely some loss of SlaB during the initial steps of the axtraction protocol due to strong attachment to membrane lipids. The final SlaB extradontained no other proteins detectable by SDS-PAGE or mass spectrometry, and no other lipids detectable using our HPLC-MS methods. Despite this, the SlaB proteins sti Deluted from the size exclusion chromatography column in the exclusion peak. This aggests that SlaB proteins strongly associate with one another, likely due to interactions between monomers, likely due to hydrophobic interactions between their N-terninal transmembrane domains.

Very little is currently known about the of SlaB. The SlaB anchor protein of $S$. solfataricus are predicted by its primgy structure to be shorter than that of S. acidocaldarius, containing fewer beta sandwich doynains (Veith et al. 2009). Correspondingly, the pseudoperiplasmic space created by the SlaB protein varies in height between the Sulfolobales, from $18 \mathrm{~nm}$ in Sulfolobus shibatad(Baumeister et al. 1989) to $27 \mathrm{~nm}$ in S. acidocaldarius (Kish et al. 2016). A recent study $\triangle$ slaB mutants in Sulfolobus islandicus suggests that the S-layer anchoring role of Slapgan be partially complemented by another S-layer associated protein, designated M164_1049 (Zhang et al. 2019). Another recent study in Sulfolobus solfataricus used CRISPR-m stated silencing of gene encoding SlaB to show that in addition to its anchoring rolo $31 \mathrm{laB}$ is important in virus susceptibility, cell morphology, and cell division (Zink et al 809 ).

Thes oindings allow deeper study of the individual components of the essential cell envelope sts sture. This is of particular importance given the current absence of tertiary structures for varchaeal S-layers, with the sole exception of the C-terminal domain of the Methanosarcina acetivorans S-layer protein (Arbing et al. 2012). Extracted S-layers have been used in a range of biotechnology applications, from nanomaterials and bioremediation applications, to immobilized biocatalysts, biochips, and drug delivery (Selenska-Pobel et al. 2011; Bartolomé et al. 2012; Sleytr et al. 2014). Historically, S-layer protein purity is often verified in relation to other proteins by SDS-PAGE. Our results show the importance of analyzing for any attached lipids to ensure protein purity prior to any sensitive downstream applications. Taken together, the findings of this study will permit greater precision when isolating and studying 
the S-layer components of Archaea, including their self-assembly, and interactions with other macromolecules as well as ions and molecules in the extracellular environment.

Acknowledgments. This project was supported by grants to A. Kish from the CNRS MITI program Xlife, and the MNHN (AVIV "Projet Féderateur"). The authors wish to thank Christelle Anquetil for help with HPLC-MS analysis of GDGTs.

\section{References:}

Albers S-V, Meyer BH (2011) The archaeal cell envelope. Nat Rev Micro 9:414-426. doi: $10.1038 /$ nrmicro 2576

Arbing MA, Chan S, Shin A, et al (2012) Structure of the surface layer of the methanofenic archaean Methanosarcina acetivorans. Proc Natl Acad Sci USA 109:11812-11817. doi: 10.1073/pnas. 1120595109

Bartolomé J, Bartolomé J, Bartolomé F, et al (2012) Strong paramagnetisnolf gold nanoparticles deposited on a Sulfolobus acidocaldarius S layer. Pha Rev Lett 109:247203. doi: 10.1103/PhysRevLett.109.247203

Baumeister W, Wildhaber I, Phipps BM (1989) Principles of organization in eubacterial and archaebacterial surface proteins. 35:215-227.

Brock TD, Brock KM, Belly RT, Weiss RL (1972) Sulfobus: a new genus of sulfuroxidizing bacteria living at low pH and high tengrature. Arch Mikrobiol 84:54-68.

Chandramohan A, Duprat E, Remusat L, et al (1918) Novel Mechanism for Surface Layer Shedding and Regenerating in Bacteria posed to Metal-Contaminated Conditions. 9:3210. doi: 10.3389/fmicb.2018.03

Claus H, Akça E, Debaerdemaeker Jet al (2005) Molecular organization of selected prokaryotic S-layer proteins. S:731-743. doi: 10.1139/w05-093

Engelhardt H (2007a) Are s tyers exoskeletons? The basic function of protein surface layers revisited. J Structura lology 160:115-124. doi: 10.1016/j.jsb.2007.08.003

Engelhardt H (2007b) Mechanism of osmoprotection by archaeal S-layers: a theoretical study. J Stru@iral Biology 160:190-199. doi: 10.1016/j.jsb.2007.08.004

Farci D, Slayo C, Piano D. 2017. Coexisting properties of thermostability and ultraviolet radian resistance in the main S-layer complex of Deinococcus radiodurans. P(1) tochem Photobiol Sci 17:1-8. doi: 10.1039/c7pp00240h

Fos P, Villa M, Burlini N, et al (1991) Intracellular proteases from the extremely thermophilic archaebacterium Sulfolobus solfataricus. Experientia 47:1057-1060. doi: 10.1007/BF01923341

Gambelli L, Meyer BH, McLaren M, Sanders K, Quax TEF, Gold VAM, Albers S-V, Daum B. 2019. Architecture and modular assembly of Sulfolobus S-layers revealed by electron cryotomography. Proc Natl Acad Sci USA 8:1-9. doi: 10.1073/pnas.1911262116 
Grogan DW (1989) Phenotypic characterization of the archaebacterial genus Sulfolobus: comparison of five wild-type strains. J Bacteriol 171:6710-6719. doi: $10.1128 /$ jb.171.12.6710-6719.1989

Grogan DW (1996) Organization and interactions of cell envelope proteins of the extreme thermoacidophile Sulfolobus acidocaldarius. Can J Microbiol 42:1163-1171. doi: 10.1139/m96-148

Guan Z, Delago A, Nußbaum P, et al (2016) N-glycosylation in the thermoacidophilic archaeon Sulfolobus acidocaldarius involves a short dolichol pyrophosphate carrier. FEBS Letters 590:3168-3178. doi: 10.1002/1873-3468.12341

Guan Z, Naparstek S, Calo D, Eichler J (2012) Protein glycosylation as an adaptivf Pense in Archaea: growth at different salt concentrations leads to alterations in Haverax volcanii S-layer glycoprotein N-glycosylation. Environmental Microbioles 14:743-753. doi: $10.1111 /$ j. 1462-2920.2011.02625.x

Hopmans EC, Schouten S, Pancost RD, et al (2000) Analysis of intaditetraether lipids in archaeal cell material and sediments by high performance liqu 0 . chromatography/atmospheric pressure chemical ionization mass spectrometry. Rapid Commun Mass Spectrom 14:585-589. doi: 10.1002/(SICOT0970231(20000415)14:7<585::AID-RCM913>3.0.CO;2-NO

Huguet A, Coffinet S, Roussel A, et al (2019) Evaluation of 3-hydroxy fatty acids as a pH

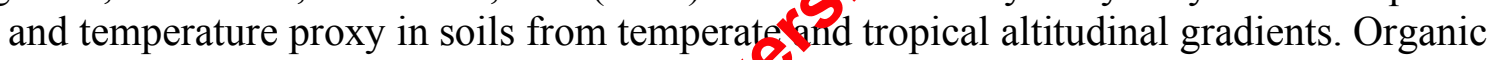
Geochemistry 129:1-13. doi: 10.1016/j.orgdeochem.2019.01.002

Huguet A, Fosse C, Laggoun-Défarge F Nol (2013) Effects of a short-term experimental microclimate warming on the abundance and distribution of branched GDGTs in a French peatland. Geochimica etsochimica Acta 105:294-315. doi: 10.1016/j.gca.2012.11.037

Im S, Joe M, Kim D, et al (2A3) Transcriptome analysis of salt-stressed Deinococcus radiodurans and chacterization of salt-sensitive mutants. Res Microbiol 164:923-932. doi: 10.1016/j.res.ric.2013.07.005

Kish A, Miot J, Iombard C, et al (2016) Preservation of Archaeal Surface Layer Structure During NGralization. Sci Rep 6:26152-10. doi: 10.1038/srep26152

Konrad Z,Eichler J (2002) Lipid modification of proteins in Archaea: attachment of a (ovalonic acid-based lipid moiety to the surface-layer glycoprotein of Haloferax olcanii follows protein translocation. Biochem J 366:959-964. doi: 10.1042/BJ20020757

König H, Stetter KO (1986) Studies on archaebacterial S-layers. Syst Appl Microbiol 7:300 309. doi: 10.1016/S0723-2020(86)80023-6

Lembcke G, Dürr R, Hegerl R, Baumeister W (1991) Image analysis and processing of an imperfect two-dimensional crystal: the surface layer of the archaebacterium Sulfolobus acidocaldarius re-investigated. J Microsc 161:263-278. doi: 10.1111/j.13652818.1991.tb03089.x 
Mader C, Küpcü S, Sara M, Sleytr UB (1999) Stabilizing effect of an S-layer on liposomes towards thermal or mechanical stress. BBA Biomembranes 1418:106-116.

Merroun ML, Raff J, Rossberg A, et al (2005) Complexation of uranium by cells and S-layer sheets of Bacillus sphaericus JG-A12. Appl Environ Microbiol 71:5532-5543. doi: 10.1128/AEM.71.9.5532-5543.2005

Michel H, Neugebauer DC, Oesterhelt D (1980) The 2-D Crystalline Cell Wall of Sulfolobus acidocaldarius: Structure, Solubilization, and Reassembly. In: Electron Microscopy at Molecular Dimensions. Springer, Berlin, Heidelberg, Berlin, Heidelberg, pp 27-35

Peyfoon E, Meyer B, Hitchen PG, et al (2010) The S-layer glycoprotein of the crenare aeote Sulfolobus acidocaldarius is glycosylated at multiple sites with chitobiose-link $12 \mathrm{~N}$ glycans. Archaea. doi: 10.1155/2010/754101

Pineda De Castro LF, Dopson M, Friedman R (2016) Biological Membrands in Extreme Conditions: Anionic Tetraether Lipid Membranes and Their Interas Dis with Sodium and Potassium. J Phys Chem B 120:10628-10634. doi: 10.1021/ats.jpcb.6b06206

Reitz T, Rossberg A, Barkleit A, et al (2015) Spectroscopic study on uranyl carboxylate complexes formed at the surface layer of Sulfolobus acidoaldarius. Dalton Trans 44:2684-2692. doi: 10.1039/c4dt02555e

Rodrigues-Oliveira T, Belmok A, Vasconcellos D, ef 2017) Archaeal S-Layers: Overview and Current State of the Art. 8:2597. doi: 10.3 89 /fmicb.2017.02597

Selenska-Pobel S, Reitz T, Schöneman R, et d (2011) Magnetic Au nanoparticles on archaeal S-Layer ghosts as templates. Nanomaarials and Nanotechnology 1:8-16.

Sleytr UB, Schuster B, Egelseer EM Ct al (2011) Nanobiotechnology with S-layer proteins as building blocks. Prog Mol Bifgransl Sci 103:277-352. doi: 10.1016/B978-0-12415906-8.00003-0

Sleytr UB, Schuster B, Eg 9 seer EM, Pum D (2014) S-layers: principles and applications. FEMS Microbiol get 38:823-864. doi: 10.1111/1574-6976.12063

Ucisik MH, Sleyt UB, Schuster B (2015) Emulsomes meet S-layer proteins: an emerging targeted dr\& delivery system. Curr Pharm Biotechnol 16:392-405.

Veith A, Mingl A, Zolghadr B, et al (2009) Acidianus, Sulfolobus and Metallosphaera sy fiace layers: structure, composition and gene expression. Mol Microbiol 73:58-72. doi: O.1111/j.1365-2958.2009.06746.x

Q.

Weiss RL (1974) Subunit cell wall of Sulfolobus acidocaldarius. J Bacteriol 118:275-284.

Zeng Z, Liu X-L, Farley KR, et al (2019) GDGT cyclization proteins identify the dominant archaeal sources of tetraether lipids in the ocean. Proc Natl Acad Sci USA 12:201909306-7. doi: 10.1073/pnas.1909306116

Zhang C, Wipfler RL, Li Y, et al (2019) Cell Structure Changes in the Hyperthermophilic Crenarchaeon Sulfolobus islandicus Lacking the S-Layer. doi: 10.1128/mBio.01589-19 
415 Zhu C, Guo G, Zhang F, et al (2017) Diversity in S-layers. Prog Biophys Mol Biol 123:1-15.

416 doi: 10.1016/j.pbiomolbio.2016.08.002

417 Zink IA, Pfeifer K, Wimmer E, et al (2019) CRISPR-mediated gene silencing reveals

418 involvement of the archaeal S-layer in cell division and virus infection. Nat Commun

419 10:4797-14. doi: 10.1038/s41467-019-12745-x 
Figures:

421

422

423

424

425

426

427

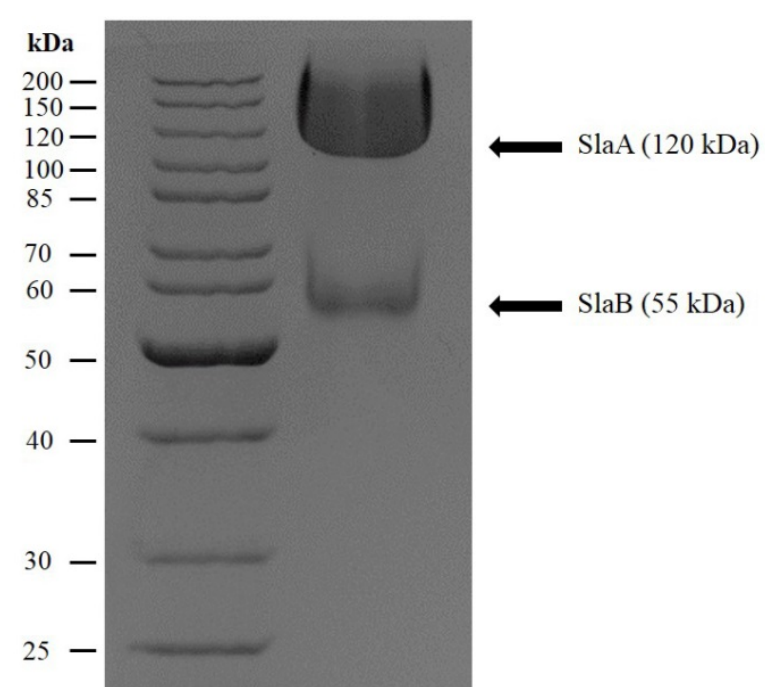

Figure 1. SDS-PAGE of extracted S-layer ghosts with two bands with apparent molecular masses around $120 \mathrm{kDa}(\mathrm{SlaA})$ and $55 \mathrm{kDa}(\mathrm{SlaB})$.
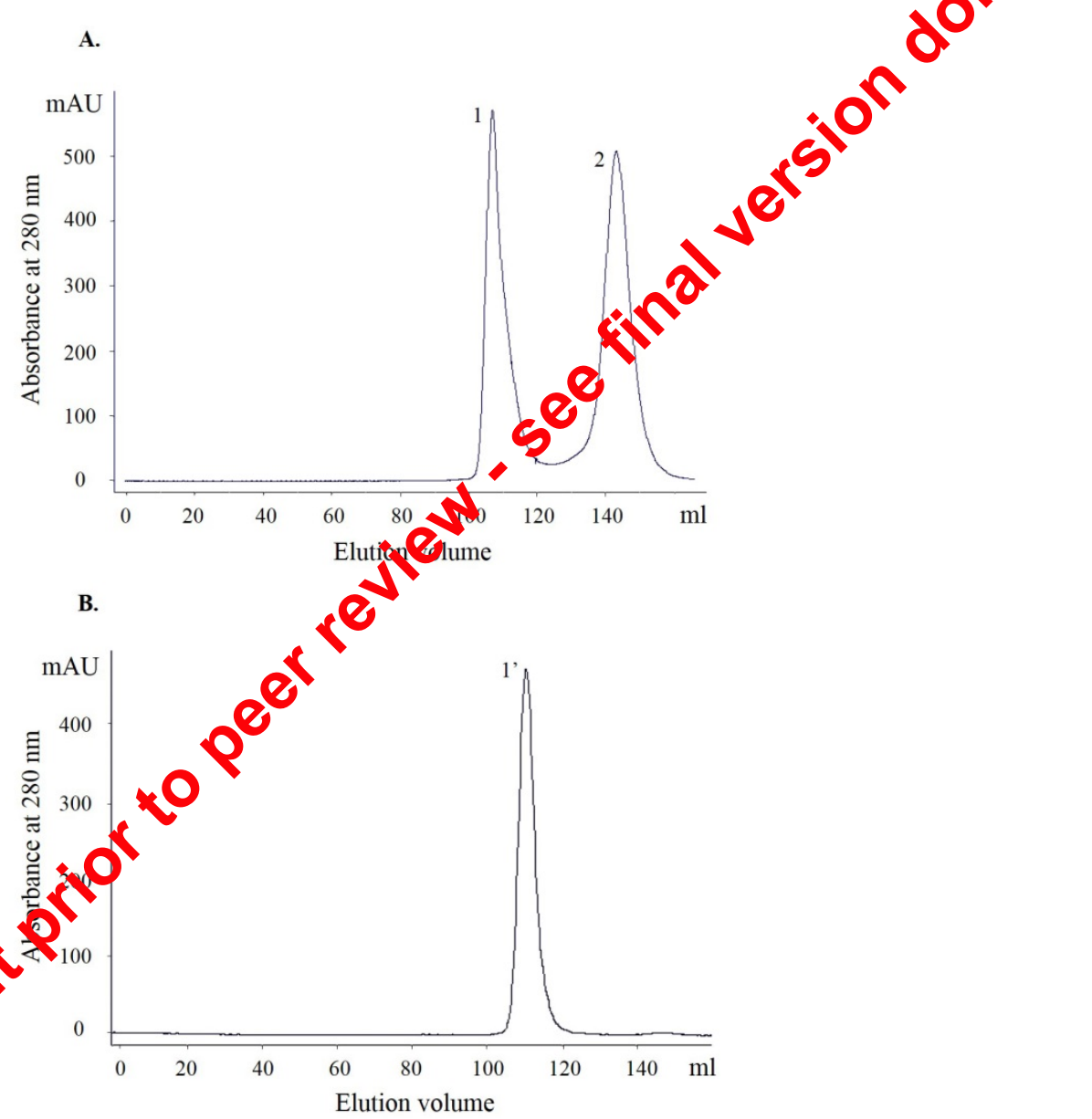

Figure 2. Separation of SlaA and SlaB protein by gel filtration chromatography. After injection of the enriched S-layer protein sample obtained by hot SDS extraction (panel A) we obtain two peaks; the peak 1 is an exclusion peak containing SlaB, whereas the peak 2 corresponds to purified SlaA monomers. To make sure that no SlaA monomers were mixed with SlaB proteins in the excluded fraction, this fraction was then reinjected and separated by 
gel filtration (panel B). The resulting exclusion peak exclusion (peak 1') shows that no

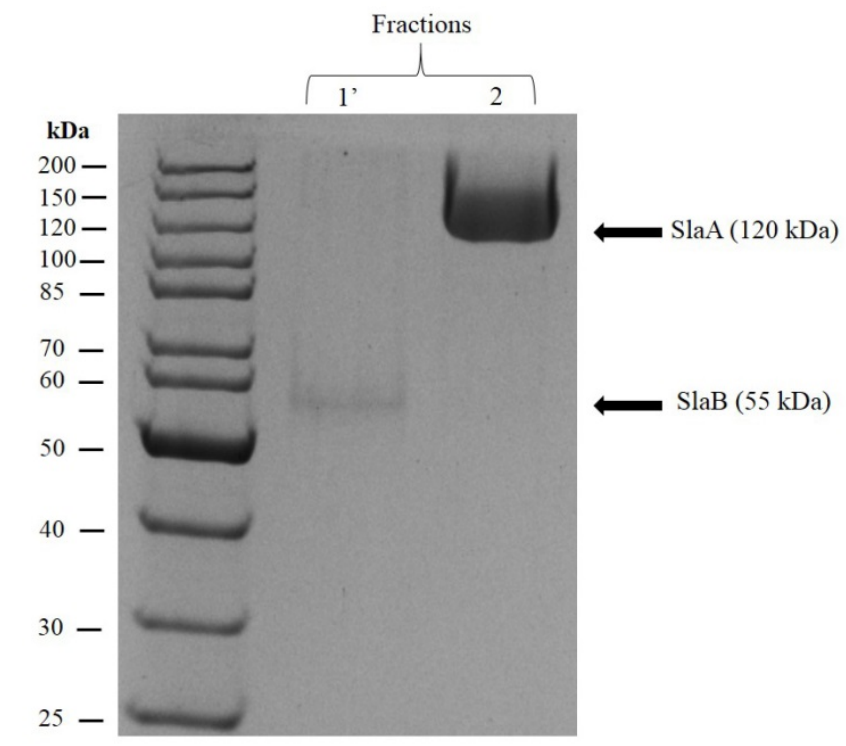

438 Figure 3. SDS-PAGE of fractions (1') and (2), resulting from the, first and second injections 439 into the gel filtration column, respectively. The bands corresond to the expected apparent 440 molecular masses of SlaA and SlaB, showing that each protein extract is now free of other 441 polypeptides.

442

443
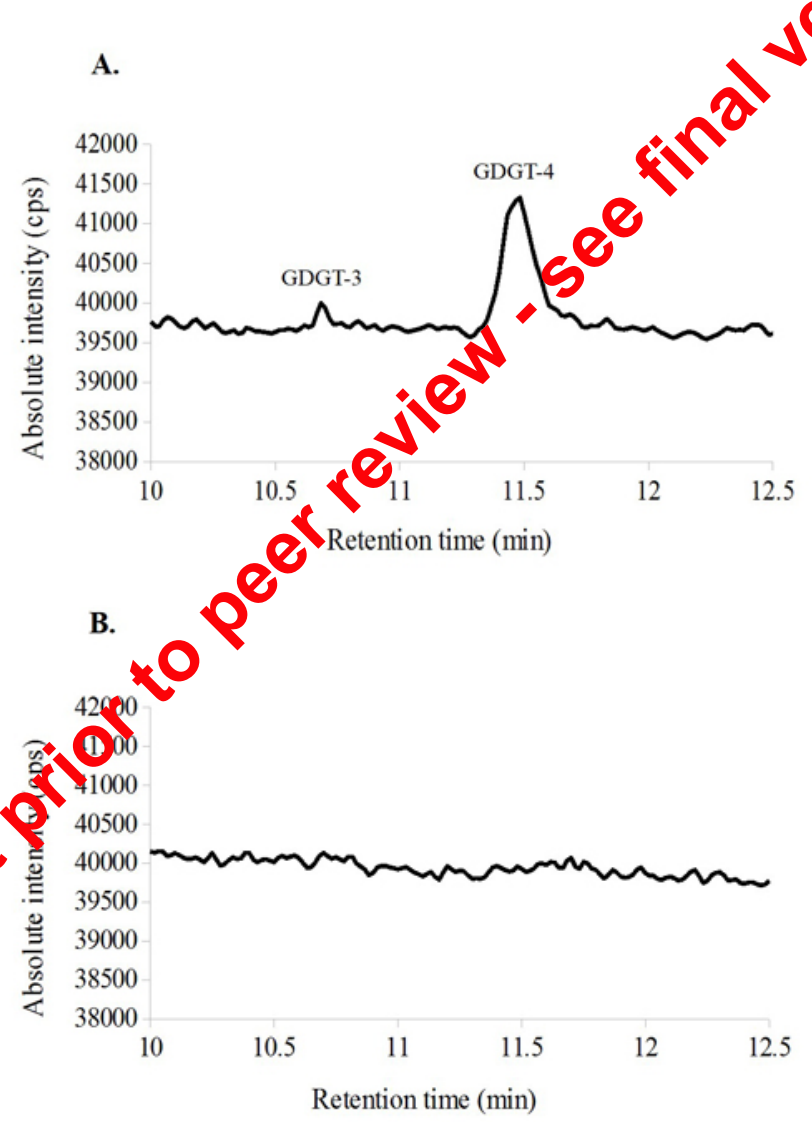
446 Figure 4. HPLC/MS identification of tetraether lipids present in samples of purified SlaB 447 before (panel A) and after (panel B) lipid extraction. The chromatograms show the absolute 448 intensity as a function of retention time. 